\title{
The Effect of the US Sanctions on Humanitarian Aids during the Great Flood of Iran in 2019
}

\author{
Mahmoudreza Peyravi; ${ }^{1,2}$ (1) Milad Ahmadi Marzaleh ${ }^{3}$ (1)
}

1. Assistant Professor, Department of Health in Disasters and Emergencies, Health Human Resources Research Center, School of Management and Medical Informatics, Shiraz University of Medical Sciences, Shiraz, Iran

2. Research Center for Emergency and Disaster Resilience, Red Crescent society of the Islamic Republic of Iran, Tehran, Iran

3. $\mathrm{PhD}$ of Health in Disasters and Emergencies, Student Research Committee, Department of Health in Disasters and Emergencies, Health Human Resources Research Center, School of Management and Medical Informatics, Shiraz University of Medical Sciences, Shiraz, Iran

\section{Correspondence: \\ Milad Ahmadi Marzaleh \\ $\mathrm{PhD}$ of Health in Disasters and Emergencies Student Research Committee \\ Department of Health in Disasters and Emergencies \\ Health Human Resources Research Center \\ School of Management and Medical \\ Informatics \\ Shiraz University of Medical Sciences, Shiraz, Iran \\ E-mail: miladahmadimarzaleh@yahoo.com}

\section{Conflicts of interest: none}

Keywords: disaster; flood; health; humanitarian aid; Iran; sanction

Received: September 18, 2019

Accepted: November 11, 2019

doi:10.1017/S1049023X20000242

(C) World Association for Disaster and

Emergency Medicine 2020.
Peyravi M, Ahmadi Marzaleh M. The effect of the US sanctions on humanitarian aids during the great flood of Iran in 2019. Prehosp Disaster Med. 2020;35(2):233-234.

\section{Dear Editor,}

Since World War I, sanctions have been imposed against international governments and organizations as a component of the common policy of many states. ${ }^{1}$ In this context, economic sanctions exert the greatest impacts on countries. ${ }^{2}$ During the occurrence of natural disasters, hostile countries also impose tyrannical bans on other territories, the last example of which being the United States' cruel sanctions against relief and rescue during the great flood of Iran in 2019. On March 17, 2019, a very heavy rain occurred in the north, center, and west of Iran. These rainfalls influenced 25 provinces, but Golestan, Khuzestan, and Lorestan provinces sustained the largest damages. Indeed, the local and national infrastructures of the country were intensely damaged and two million Iranians were influenced.

Iran's Red Crescent Society (Tehran, Iran) played an important role in relief operations during this flood. The Red Crescent Society is an impartial and relieving organization in the course of natural disasters, which takes various measures, including relief and rescue, emergency accommodation, distribution of people's contributions, and dispersion of supportive packages. Red Crescent is an international organization, but it suffered the largest impacts by the sanctions. The US's unilateral sanctions against Iran caused the international aids usually sent by various supportive countries and organizations during disasters not to be delivered to the Red Crescent Society on time.

In the meantime, the US's unilateral sanctions do not practically have an effect on humanitarian aids, but the secondary sanctions pertaining to the US's relations with the European and Asian countries prevented the relief operations from being properly undertaken. They even created constraints on the purchase of the required items. However, noncash contributions by other countries to flood-stricken people in Iran were made almost without any problems. Of course, contribution of such dual-use equipment as helicopter and rescue boats that can be used for military purposes was confronted with problems. The entry of cash contributions into Iran was one of the toughest sanction-caused bottlenecks. For example, Red Cross Society and humanitarian people, volunteers, and organizations as well as the Iranian residents of other countries could not make financial contributions to the country. Based on the United Nation's resolutions, medications, medical commodities, and civil airplanes' spare parts should not be included in sanctions. However, their entry into Iran was faced with problems because these items required financial payments.

The UN's contributions were mostly directed at establishing camps and meeting the flood-stricken people's emergency needs. The fact is that the UN encountered problems even for transferring money to its own personnel as a result of the US cruel sanctions. Contribution of foodstuff by the supreme commission of the refugees and the medical facilities and medications sent by the World Health Organization (WHO; Geneva, Switzerland) should not be overlooked, as well. According to the regulations and resolutions of the UN, the five priorities of health, shelter creation, foodstuff, drinkable water, and education should not be subjected to sanctions. However, American actors prevented the relief operations from occurring via influencing other countries around the globe.

The following solutions can be made for fighting against the sanctions during natural disasters: (1) use of a block chain for making financial supplies and transferring goods during disasters; (2) exertion of pressure on the US by international organizations defending human rights and other countries for lifting the sanctions; (3) codification of the rules related to the role of governments for humanitarian aids during disasters; (4) constructive negotiation and 
interaction with the banning countries; and (5) transfer of issues to the international rights courts.

\section{Conclusion}

The US's cruel sanctions prevented the entry of cash and non-cash contributions into Iran for helping flood-stricken people, which is a clear instance of human right violation. Besides physical and financial effects on flood-stricken people, the sanctions were accompanied by psychological impacts. During natural disasters, saving the lives of injured people becomes a critical priority and political relations should not disrupt the relief operations and the delivery of contributions. However, solutions like negotiating with politicians and making pleas to the international courts of justice can be promising and resolving. Therefore, Iran expects the international community to impose pressures for making the US change its behavior parallel to its non-performance of any human right violation in the course of delivering humanitarian aids to disasterstricken regions and in line with preserving the self-esteem and veneration of the victims of such natural calamities.

\section{Acknowledgement}

The authors would like to thank Ms. A. Keivanshekouh at the Research Improvement Center of Shiraz University of Medical Sciences (Shiraz, Iran) for improving the use of English in the manuscript.

\section{References}

1. Davis L, Engerman S. History lessons: sanctions-neither war nor peace. Journal of Economic Perspectives. 2003;17(2):187-197.
2. Allen SH, Lektzian DJ. Economic sanctions: a blunt instrument? Journal of Peace Research. 2013;50(1):121-135. 